УДК 911.52

doi: $10.31251 /$ pos.v1i4.43

\title{
ОЦЕНКА СОСТОЯНИЯ ОКРАИННЫХ ЧАСТЕЙ БОЛЬШОГО ВАСЮГАНСКОГО БОЛОТА (НА ПРИМЕРЕ БАКЧАРСКОГО БОЛОТНОГО МАССИВА)
}

\author{
(C) 2018 А.А. Синюткина, Л.П. Гашкова
}

Адрес: Сибирский научно-исследовательский институт сельского хозяйства и торфа, филиал СФНЦА, 634050, г. Томск, ул. Гагарина 3, Россия. E-mail: ankalaeva@yandex.ru

\begin{abstract}
Цель исследования. Проведение комплексной оценки состояния лесоболотного экотона Бакчарского болотного массива (подзона южной тайги, Западная Сибирь).

Место и время проведения. Ключевой участок в бассейне р. Ключ (56 $58^{\prime}$ с.ш.; 82³6' в.д.) в пределах Бакчарского болотного массива в период 2017-2018 г2.

Методология. Использованы методы георадиолокации, полевых ландиафтных исследований, геоинформационного моделирования.

Основные результаты. В пределах ключевого участка преобладают заболоченные смешанные леса $c$ доминированием березы на торфяных маломощңных почвах. Микрорельеф поверхности сильно расчлененный, среднее значение среднеквадратического отклонения высот составляет 14, при средней амплитуде колебаний высот 58,4 см. Увлажнение местообитания находится в прямой зависимости от амплитуды колебаний высот, что делает иелесообразным использование количественных показателей микрорельефа при оченке гидроморфной трансформации лесоболотных экотонов. Основная часть территории относится к сыро-лесолуговой ступени увлажнения местообитаний; балль увлажнения участков в соответствии с экологической шкалой Д.Н. Цыганова изменяются в пределах 14,2-15,7. Статистический анализ показал, что увлажнение местообитаний определяется главным образом углами наклона минерального дна, а мощьость торфяной залежи находится в прямой зависимости с углом наклона современной поверхности. В результате торфонакопления произошло выравнивание поверхности и уменьшение средних углов наклона с $0,23^{\circ}$ до $0,15^{\circ}$, что будет способствовать дальнейтей гидроморфной трансформации участка.

Заключение. В результате комплексной оченки состояния лесоболотного экотона Бакчарского болотного массива получены новые данные о трансформации поверхности в результате торфонакопления, проведена количественная оченка вклада рельефа, как основного фактора заболачивания территории. Полученные данные могут быть использована как основа для разработки прогнозных моделей прочессов заболачивания прилегающих $к$ болотам территорий $u$ оценки роли расширения площчадей болот в динамике глобального ичикла углерода.
\end{abstract}

Ключевые слова: геоинформачионное моделирование; георадиолокачия; заболоченный лес; микрорельеф поверхности; торфяная залежь; заболачивание

Цитирование: Синюткина А.А., Гашкова Л.П. Оценка состояния окраинньх частей Большого Васюганского болота (на примере Бакчарского болотного массива) // Почвы и окружающая среда. 2018. № 1(4). C. $243-255$.

\section{ВВЕДЕНИЕ}

Ежегодно в мире заболачивается около 66 тыс. га земли (Бабиков, Кобак, 2016). Проблема гидроморфной трансформации особенно актуальна для территории Западной Сибири, заболоченность которой в среднем составляет $30 \%$, а на территории таежной зоны достигает $50 \%$ (Лисс и др., 2001, Евсеева и др., 2012). Переход болот на данной территории в олиготрофную фазу развития и приобретение их поверхностью выпуклой формы определяет их активное воздействие на прилегающие растительные группировки. По данным Б.В. Бабикова и К.И. Кобак (2016), в настоящее время процессы заболачивания активизируются вследствие глобального изменения климата и, прежде всего, за счет увеличения количества осадков. Наряду с глобальными и региональными климатическими условиями на развитие процесса заболачивания существенное влияние оказывают локальные факторы болотообразования, к которым относятся морфометрические характеристики поверхности, остающиеся в настоящее время наименее изученными (Graniero, Price, 1999; Laamrani et al., 2014). В зависимости от геоморфологических условий возможно как интенсивное заболачивание, так и сокращение площадей болот (Инишева, Березина, 2013).

Существующая в настоящее время проблема неоднозначности оценок тренда заболачивания и интенсивности аккумуляции торфа в условиях изменяющего климата определяет необходимость 
пространственных структур ландшафтного покрова болот и лесоболотных экотонов с использованием современных методов сбора и обработки материалов полевых исследований, в том числе с применением метода георадиолокации. Ряд авторов подчеркивают преимущества использования георадиолокации в сравнении с контактными измерениями на точках за счет их большей детальности и высокого пространственного разрешения (до нескольких см вдоль линии профиля), чего невозможно достичь с использованием традиционных методов (Ulriksen, 1980; Sass et al., 2010; Walter et al., 2016).

Цель исследования заключалась в проведении комплексной оценки состояния лесоболотного экотона Бакчарского болотного массива с учетом влияния геоморфологических факторов на развитие процесса заболачивания. Основными источниками информации являются данные георадиолокационной съемки торфяной залежи и минерального дна болота/заболоченного леса, тахеометрической и нивелирной съемки геоморфологических профилей и микрорельефа поверхности заболоченного леса, полевых ландшафтных описаний на точках.

\section{ОБЪЕКТ И МЕТОДЫ ИССЛЕДОВАНИЯ}

Объектом исследования является ключевой участок площадью 0,24 км $^{2}$ в бассейне р. Ключ (правый приток р. Бакчар, бассейн р. Чая, подзона южной тайги Западной Сибири), включающий окраинную часть Бакчарского болота, прилегающие к нему заболоченные и суходольные леса (рис.1). Четвертичные отложения представлены озерно-аллювиальными глинами и суглинками, мощность которых достигает 40-60 м (Западная Сибирь, 1963). Территория характеризуется практически плоским рельефом; значения вертикального расчленения не превышают 10 м, и горизонтальное расчленение рельефа изменяется в пределах 0,6-1,25 км/км². Климат континентальный с длинной холодной зимой и коротким теплым летом. Средняя годовая температура составляет $0,23^{\circ} \mathrm{C}$, среднегодовое количество осадков 473 мм, суммарное годовое испарение достигает 332 мм. Отмечены тенденции к увеличению сумм атмосферных осадков, что приводит к росту избытка увлажнения и способствует усилению болотообразовательного процесса, в особенности в условиях плоского рельефа и слабой водопроницаемости грунтов (Евсеева и др., 2012). Для растительного покрова территории исследования характерна смена растительных сообществ от кедрово-соснового и березовососнового травяно-сфагнового верхового болота, протягивающегося узкой полосой вдоль границы Бакчарского болотного массива, на сосново-кустарничково-сфагновое болото, занимающее значительные площади на склоне болотного массива. В центральной части болотного массива широкое распространение получили грядово-мочажинные и грядово-озерковые комплексные сосновокустарничково-травяно-сфагновые болота. Вдоль границы болотного массива протягивается полоса заболоченного, протяженностью 1,5-4 км, соответствующая склону водораздельной равнины (Чудиновская, Синюткина, 2018).
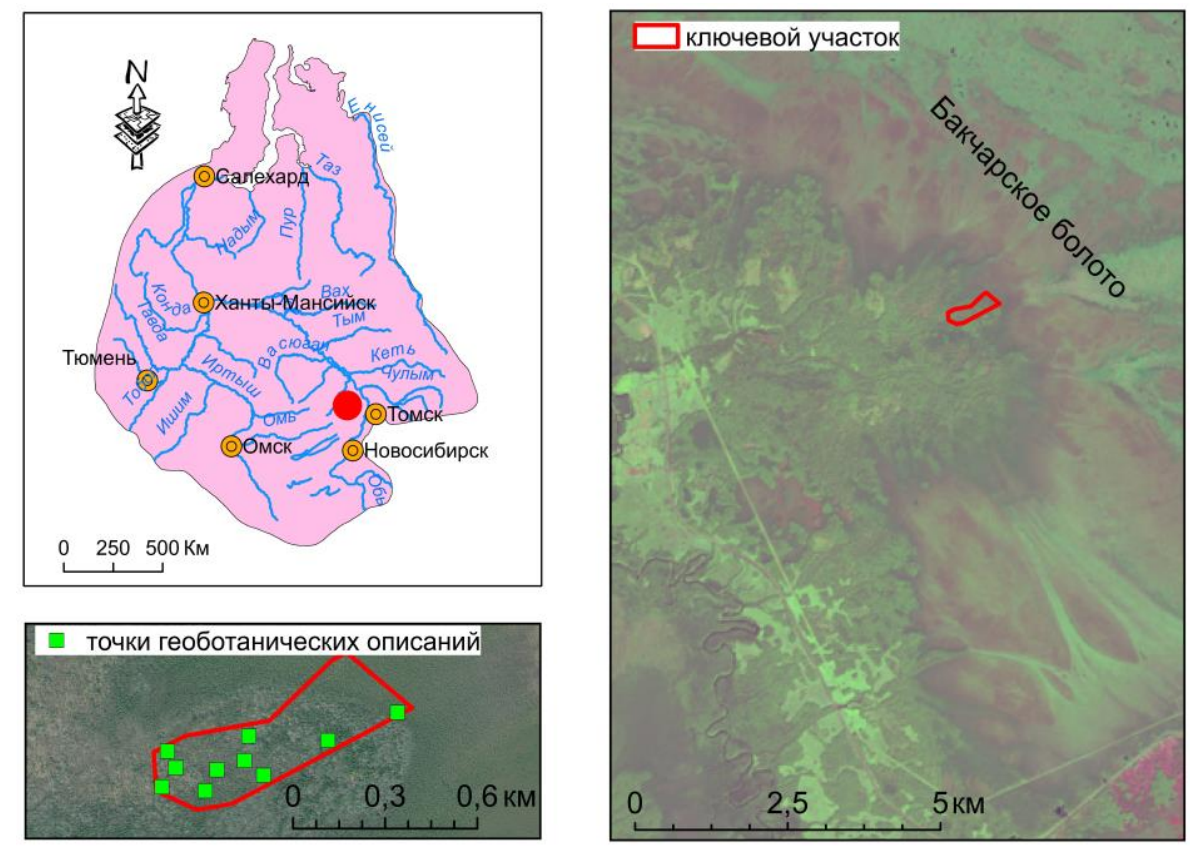

Рисунок 1. Схема расположения объекта исследования 
На современном этапе развития болота являются мощным фактором почвообразования, что определяется постоянным гравитационным стоком влаги с выпуклых болотных массивов и крайне низкими значениями водопроницаемости почвообразующих пород. Гидроморфная трансформация почв наиболее активно протекает на территориях, прилегающих к болотным массивам, и проявляется в накоплении на поверхности органогенных горизонтов в условиях постоянного переувлажнения или формировании элювиального горизонта в условиях переменного увлажнения (Никифоров, Дюкарев, 2015).

Методика проведения полевых исследований включала ряд этапов:

1. Проведение георадарной съемки с использованием георадара ОКО-2 в комплекте с экранированным антенным блоком (частота зондирования 250 МГц, развертка по глубине 200 нс, шаг зондирования 5 см). Съемка выполнена в марте 2018 года, общая протяженность георадарных профилей составила 2,3 км. Пространственная привязка профилей проведена с использованием датчика перемещения и GPS навигатора. В процессе съемки устанавливались метки на радарограмме, соответствующие точкам контактных измерений.

2. Контактные исследования на опорных точках. В соответствии с установленными метками на радарограмме в летний период 2018 года выполнено контактное зондирование торфяной залежи на 33 точках, включающие определение мощности торфяной залежи, выделение стратиграфических горизонтов по видам и степени разложения торфа визуальным методом (Тюремнов, 1976). Проведен отбор образцов торфа на 4 точках для определения ботанического состава и степени разложения под микроскопом. Выполнены геоботанические описания и описания микрорельефа поверхности, проведено определение уровня болотных вод от средней поверхности болота на 12 площадках. Определение высоты деревьев проведено с использованием лазерного дальномера Nicon Forestry Pro (Nikon Vision Co., Japan). Проведена съемка профиля вертикального сечения горизонта формирования микрорельефа с использованием тахеометра на 10 площадках (300 измерений). Для построения цифровых моделей рельефа проведена нивелирная съемка поверхности ключевого участка.

3.Обработка и интерпретация данных георадиолокации проведена с использованием программы GeoScan32 (ОOO «Логические системы», Россия). Подготовка данных к интерпретации заключалась в удалении постоянной составляющей сигнала (инструмент «удаление среднего»), усиление сигнала в нижней части профиля, определении нуля шкалы глубин. Выделение основных элементов георадарного профиля (георадарных комплексов) выполнено по конфигурации, интенсивности и протяженности осей синфазности, частотного состава записи, скорости распространения волны. Определение диэлектрической проницаемости и расчет глубин залегания горизонтов торфа проведено путем сопоставления глубин расположения границ между выделенными георадарными комплексами во временной шкале с данными контактных измерений на опорных точках (Каширо и др., 2018). Статистический анализ данных измерений микрорельефа модельных участков включал определение показателей, характеризующих расчлененность микрорельефа (амплитуда колебаний высот, амплитуда колебаний высот при уровне значимости $\mathrm{P}=0,05$, среднеквадратическое отклонение) и распределение высот относительно средней поверхности болота (доля высот в интервале от -5 до 5 см, доля высот выше средней поверхности). Выявление зависимостей показателей микрорельефа от характеристик древесного яруса и увлажнения местообитаний проведено с использованием факторного анализа (Синюткина и др.,2018). Определение ступеней экологической шкалы увлажнения почв для местообитаний вдоль линии профиля проведено в соответствии с (Цыганов,1983, Прокопьев, 2001) (табл.1) с учетом удельного веса проективного покрытия видов. Расстояние от границы болотного массива рассчитано с использованием методов геоинформационного картографирования. Граница болотного массива на данном участке соответствует смене фитоценозов заболоченного леса на болотный березово-сосновокустарничково-травяно-сфагновый.

Статистическая обработка данных проведена с использованием метода главных компонент для выявления ведущих геоморфологических факторов, определяющих формирование видовой структуры растительного покрова в соответствии с экологической шкалой увлажнения местообитаний. Статистическая обработка данных проведена с использованием R пакета (www.rproject.org). 
Шкала увлажнения местообитаний (Цыганов, 1983)

\begin{tabular}{|c|c|}
\hline Балл & Экологическая группа \\
\hline 12 & свеже-лесолуговая \\
\hline 13 & влажно-лесолуговая \\
\hline 14 & сыровато-лесолуговая \\
\hline 15 & сыро-лесолуговая \\
\hline 16 & мокро-лесолуговая \\
\hline 17 & болотно-лесолуговая \\
\hline 18 & субболотная \\
\hline 19 & болотная \\
\hline
\end{tabular}

РЕЗУЛЬТАТЫ ИССЛЕДОВАНИЯ

Растительность. В пределах ключевого участка широкое распространение получили заболоченные смешанные леса с преобладанием березы (Betula pubescens Ehrh.) (табл.2). Субдоминантами древесного яруса являются кедр (Pinus sibirica Du Tour), сосна (Pinus sylvestris L.), ель (Picea obovata Ledeb), осина (Populus tremula L.). Высота древесного яруса изменяется в пределах 15-22 м, сомкнутость крон 20-60\%. Типичными представителями кустарникового яруса являются смородина (Ribes nigrum L.), шиповник (Rosa acicularis Lindley), рябина (Sorbus sibirica Hedl.), малина (Rubus idaeus L.). Проективное покрытие яруса обычно не превышает 5-10\%. Среди кустарничков выделяется брусника (Vaccinium vitis-idaea L.) с проективным покрытием около 5\%, занимающая повышения микрорельефа. В травяном ярусе широко распространены различные виды осок (Carex acuta L., C. elongata L. и др.), хвощей (Equisetum palustre L., E. sylvaticum L. и др.), вейников (Calamagrostis canescens (Web.) Roth, C. neglecta (Ehrh.) Gaertn., Mey. et Scherb. дp.), папоротников (Gymnocarpium dryopteris (L.) Newm, Athyrium filix-femina (L.) Roth и др.). В моховом ярусе преобладают зеленые мхи, часто занимающие поваленные гнилые стволы и приствольные повышения. Для березово-сосново-кустарничково-осоково-сфагнового болота характерны сосна ( $P$. silvestris), береза (B. pubescens), кедр (P. sibirica) с общей сомкнутостью крон $25 \%$. Высота деревьев изменяется в пределах 8-16 м при средней высоте яруса 9,5 м. Кустарнички с проективным покрытием $30 \%$ распространены преимущественно на повышениях. Ярус образуют багульник (Ledum palustre L.), хамедафна (Chamaedaphne calyculata (L.) Moench), брусника (Vaccinium vitis-idaea L.), клюква (Oxycoccus palustris Pers.). Травяной ярус образован пушицей (Eriophorum vaginatum L.) с проективным покрытием 40 \%. Проективное покрытие мхами составляет 50 \%, широко распространены Sphagnum angustifolium (Russ.ex Russ.) C.Jens., $S$. balticum (Russ.) Russ.ex C.Jens., встречаются S. magellanicum Brid., Pleurozium schreberi (Brid.) Mitt.

Таблица 2

Характеристика участков контактных исследований

\begin{tabular}{|c|l|c|c|c|c|}
\hline № & \multicolumn{1}{|c|}{ Фитоценоз } & $\begin{array}{c}\text { Мощность } \\
\text { торфа, м }\end{array}$ & $\begin{array}{c}\text { УБВ*/УГВ**, } \\
\text { см от средней } \\
\text { поверхности }\end{array}$ & $\begin{array}{c}\text { Басстоя- } \\
\text { увлажнения }\end{array}$ & $\begin{array}{c}\text { Ние от } \\
\text { Бакчарского } \\
\text { болота, м }\end{array}$ \\
\hline 1 & \multicolumn{1}{|c|}{2} & 3 & 4 & 5 & 6 \\
\hline 1 & $\begin{array}{l}\text { Березово-сосново-кустарничково- } \\
\text { пушицево-сфагновое верховое болото }\end{array}$ & 1,4 & -10 & 15,2 & 463 \\
\hline 2 & $\begin{array}{l}\text { Кедрово-елово-березовый разнотравно- } \\
\text { злаковый заболоченный лес }\end{array}$ & 1,1 & -5 & 14,5 & 655 \\
\hline 3 & $\begin{array}{l}\text { Кедрово-сосново-березовый } \\
\text { разнотравный заболоченный лес1 }\end{array}$ & 1,0 & -10 & 14,7 & 500 \\
\hline 4 & $\begin{array}{l}\text { Кедрово-березовый разнотравно- } \\
\text { злаковый заболоченный лес }\end{array}$ & 1,0 & -10 & 15,1 & 308 \\
\hline 5 & $\begin{array}{l}\text { Кедрово-березовый разнотравно- } \\
\text { злаковый заболоченный лес }\end{array}$ & 1,0 & -15 & 15,3 \\
\hline
\end{tabular}




\begin{tabular}{|c|l|c|c|c|c|}
\hline \multicolumn{1}{|c|}{2} & 3 & 4 & 5 & 6 \\
\hline 1 & \multicolumn{1}{|c|}{ Продолжение таблицы 2 } \\
\hline 6 & $\begin{array}{l}\text { Сосново-осиново-березовый } \\
\text { разнотравный зеленомошный } \\
\text { заболоченный лес }\end{array}$ & 0,75 & -15 & 14,5 & 220 \\
\hline 7 & $\begin{array}{l}\text { Кедрово-березовый разнотравно- } \\
\text { злаковый заболоченный лес }\end{array}$ & 0,7 & 0 & 15,0 & 390 \\
\hline 8 & $\begin{array}{l}\text { Елово-сосново-березовый хвощевый } \\
\text { заболоченный лес }\end{array}$ & 0,7 & -30 & 14,2 & 148 \\
\hline 9 & $\begin{array}{l}\text { Елово-кедрово-березовый разнотравный } \\
\text { заболоченный лес }\end{array}$ & 0,5 & -10 & 14,9 & 722 \\
\hline 10 & $\begin{array}{l}\text { Кедрово-сосново-березовый } \\
\text { болотнотравный заболоченный лес }\end{array}$ & 0,3 & -10 & 15,7 & 47 \\
\hline 11 & $\begin{array}{l}\text { Елово-кедрово-березовый разнотравно- } \\
\text { злаковый заболоченный лес }\end{array}$ & 0,25 & -15 & 14,7 & 656 \\
\hline 12 & $\begin{array}{l}\text { Осиново-березово-кедровый } \\
\text { разнотравный лес }\end{array}$ & 0 & -30 & 14,8 & 526 \\
\hline & *уБВ - уровень болотных вод; \\
$* *$-уВ -уровень грунтовых вод & & & & \\
\hline
\end{tabular}

В соответствии с оценкой по шкале увлажнения (Цыганов, 1983), в пределах площадок геоботанических описаний виды относятся к 8 ступеням увлажнения от 12 до 19. Основная часть удельного веса проективного покрытия видов (83\%) относится к 14-16 ступеням увлажнения. Согласно оценке условий местообитаний методом стандартных экологических шкал, увлажнение объектов исследования изменяется в пределах 14,2-15,7 баллов и характеризуется как сыроватолесолуговое, сыро-лесолуговое и мокро-лесолуговое. Максимальное значение отмечено на расстоянии 50 м от границы Бакчарского болотного массива в пределах кедрово-сосновоберезового болотнотравного заболоченного леса. Следует отметить, что балл увлажнения данного участка превышает балл, полученный для окраинной части болотного массива, занятой березовососново-кустарничково-пушицево-сфагновым верховым болотом.

Микрорельеф поверхности. Микрорельеф заболоченного леса сильно расчлененный, с понижениями глубиной до 50 см, средние размеры которых в плане составляют 3-5 м. Положительные формы, образованные приствольными повышениями, старыми упавшими стволами и выворотнями корней, занимают $30-40 \%$ поверхности заболоченного леса. Поверхность заболоченных лесов характеризуется большими значениями показателей расчлененности рельефа в сравнении с болотами (Синюткина и др.,2017). Высокие значения среднеквадратического отклонения и амплитуды колебаний высот поверхности обусловлены наличием выворотов деревьев, определяющие образование глубоких понижений под корнями деревьев и появление положительных форм, образованных непосредственно корнями и приствольными повышениями (табл.3). Отличительной особенностью поверхности заболоченных лесов является практически полное отсутствие аккумулятивных форм микрорельефа в виде моховых подушек, что определяет превышение доли занятых отрицательными формами микрорельефа над положительными.

Таблица 3

Средние значения показателей микрорельефа заболоченных лесов

\begin{tabular}{|l|c|c|}
\hline Показатель & Среднее значение & Интервал \\
\hline Амплитуда, см & 58,4 & $43,2-68,7$ \\
\hline Квартильный размах, см & 17,6 & $14,9-22,0$ \\
\hline Среднеквадратическое отклонение & 14 & $10,2-19,1$ \\
\hline Доля высот у средней поверхности (-5-5 см), \% & 27 & $22,0-31,0$ \\
\hline Доля высот выше средней поверхности, \% & 44,4 & $38,0-51,6$ \\
\hline
\end{tabular}

Почвенный покров. Согласно классификации гидроморфных почв (Почвоведение, 1988), в пределах ключевого участка преобладают торфяные маломощные почвы с мощностью торфяного горизонта 0,7-1,0 м. Встречаются торфянисто-глеевые и торфяно-глеевые, а также торфяные среднемощные почвы в окраинной части болотного массива. Мощность торфяной залежи в пределах ключевого участка достигает 1,75 м, среднее значение 0,4 м. В стратиграфии торфяной залежи заболоченных лесов преобладают низинные древесные и древесно-травяные торфа с 
высокой степенью разложения в пределах 35-50\% (рис.2). Торфяная залежь окраинной части Бакчарского болотного массива относится к смешанному типу. Верхний горизонт до глубины 50 см сложен верховым древесно-сфагновым торфом. Далее на глубине 50-100 см залегает слой древесно-осокового низинного торфа со степенью разложения 30\%. Нижние слои сложены низинным осоково-гипновым торфом. Степень разложения торфа изменяется в пределах 20-35\%.

Использование данных георадарной съемки позволило оценить пространственную дифференциацию мощности торфяной залежи вдоль линии профиля и выявить участки с резкими перепадами глубин минерального дна за счет высокого пространственного разрешения съемки. В качестве примера на рисунке 3 показан георадарный профиль, полученный в окраинной части Бакчарского болотного массива. Начало профиля соответствует точке 1 контактных исследований (табл.2). В первой части профиля отмечено резкое увеличение мощности торфяного горизонта с 1 м до 1,70 на протяжении 20 м вдоль линии профиля, что соответствует уклону поверхности минерального дна $2^{\circ}$. Далее поверхность минерального дна практически плоская с перепадами высот в пределах 20-30 см.

A

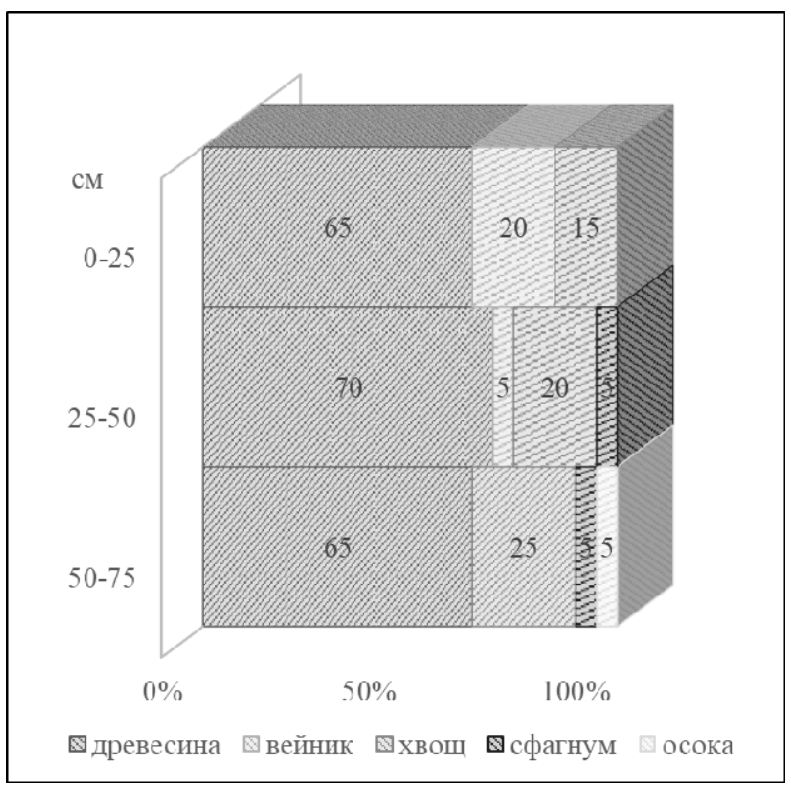

Б

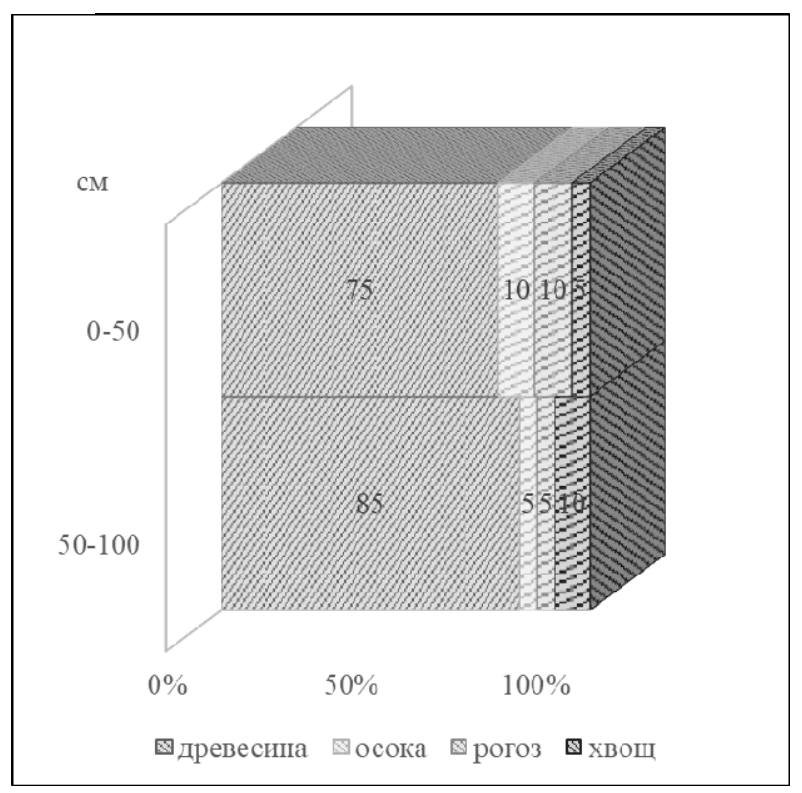

Рисунок 2. Стратиграфия торфяной залежи сосново-осиново-березового разнотравного зеленомошного заболоченного леса (А) и кедрово-сосново-березового разнотравного заболоченного леса (Б)

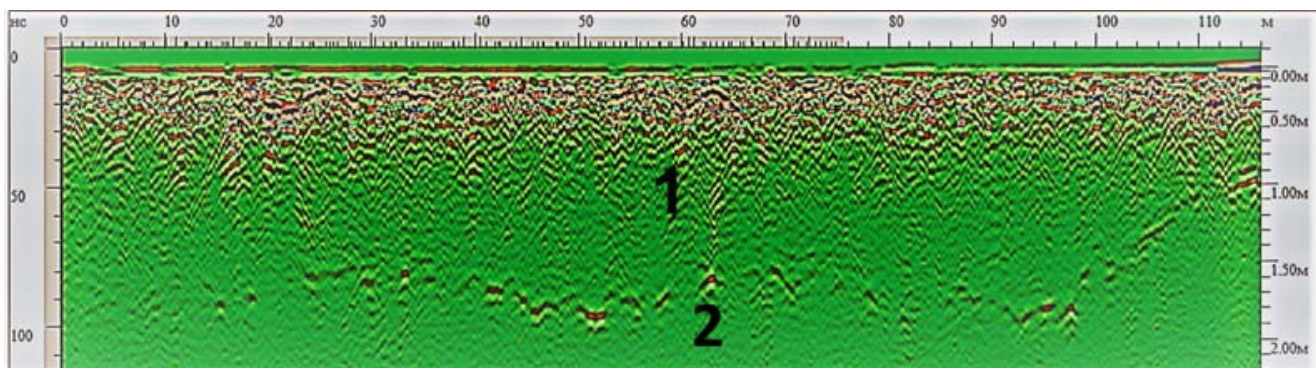

Рисунок 3. Георадарный профиль в пределах окраинной части Бакчарского болота (дата съемки 20.03.2018): 1 - торфяная залежь, 2 - отложения минерального дна

Анализ всего массива данных, полученных с использованием метода георадиолокации, в пределах ключевого участка показал отсутствие закономерностей в изменении мощности торфяного горизонта при удалении от границы болотного массива. Мощность торфяной залежи неоднородна, стандартное отклонение по данным 70 контактных и георадарных измерений составляет 0,4. Выделяется два изолированных контура с мощностью торфяной залежи более $1 \mathrm{м}$ (рис.4). Первый контур соответствует окраинной части Бакчарского болотного массива. В 
непосредственной близости с границей происходит быстрое уменьшение мощности торфяного горизонта от 1,7 в пределах березово-сосново-кустарничково-пушицево-сфагнового верхового болота до 0,3 м на расстоянии 50 м от границы болота в пределах кедрово-сосново-березового болотнотравного заболоченного леса. Второй изолированный контур, соответствующий котловине минерального дна, расположен на расстоянии 150-300 м от Бакчарского болотного массива. Дно котловины неоднородное, имеет несколько понижений, где мощность торфяной залежи достигает своего максимального значения - 1,5 м, при среднем значении 1 м и стандартном отклонении 0,2 (по данным 30 измерений) (Синюткина и др., 2018).

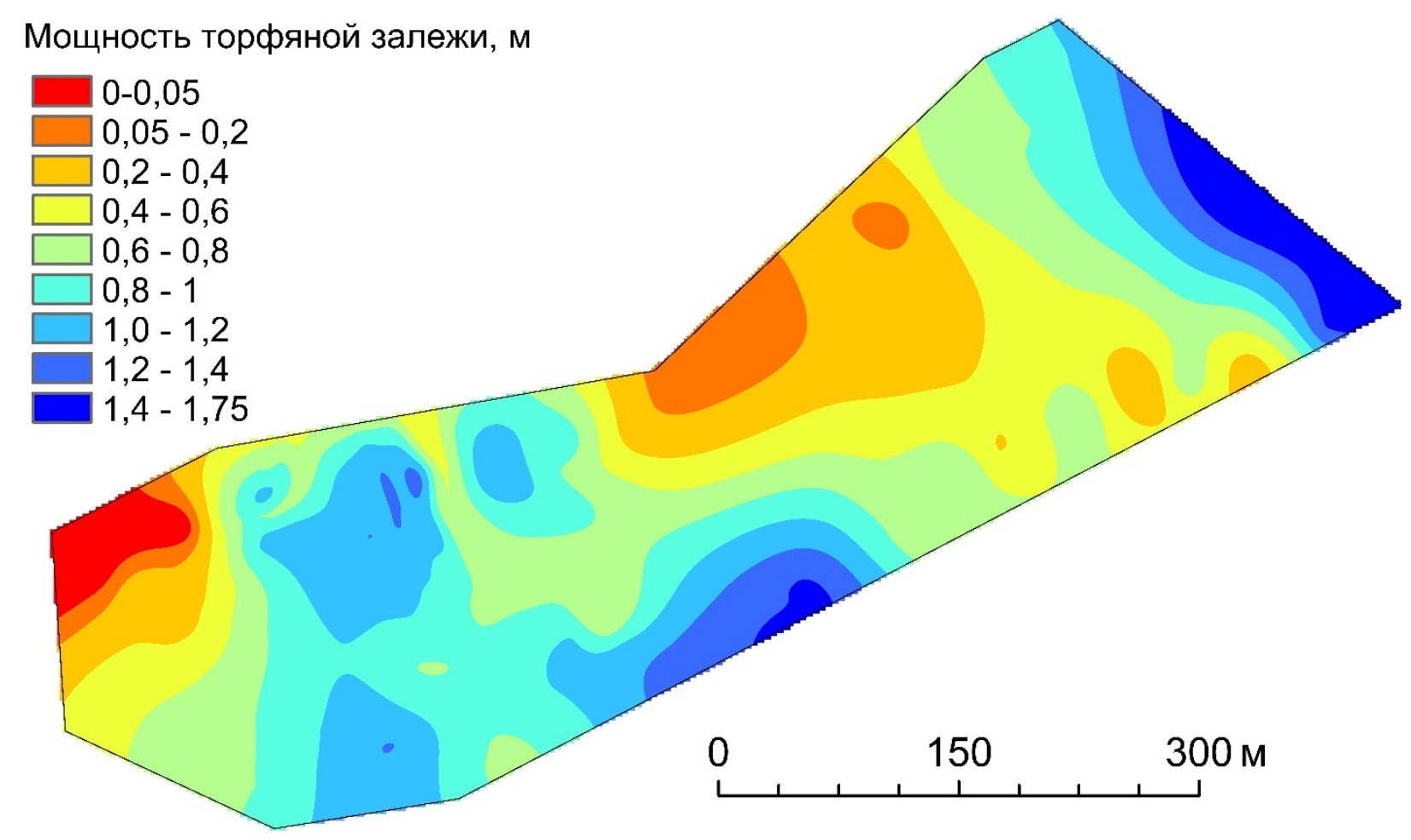

Рисунок 4. Мощность торфяной залежи ключевого участка

Рельеф минерального дна и поверхности. Поверхность ключевого участка практически ровная с общим уклоном на юго-запад. Перепад высот не превышает 2 м. При схожем значении амплитуды колебаний высот, поверхность минерального дна более расчлененная. Выделяется два понижения, в настоящее время заполненных торфом (рис. 5).

Углы наклона минерального дна ключевого участка изменяются в пределах $0-1,5^{\circ}$; на большей части территории значения не превышают $0,2-0,3^{\circ}$. Среднее значение составляет $0,23^{\circ}$, стандартное отклонение 0,15 . На участках, пространственно соответствующих склонам котловин, углы наклона минерального дна составляют около $0,5^{\circ}$. Высокие значения углов наклона, достигающие $1,0-1,5^{\circ}$, соответствуют границе заболоченного и суходольного лесов в западной части ключевого участка. Использование данных георадиолокации с высоким пространственным разрешением позволило выделить участок с экстремальным значением угла наклона поверхности $2^{\circ}$, соответствующий границе болота и заболоченного леса.

В результате развития процесса торфонакопления произошло выравнивание исходной поверхности. Среднее значение угла наклона поверхности понизилось до $0,15^{\circ}$ со стандартным отклонением 0,08 . В пределах окраинной части Бакчарского болотного массива отмечена инверсия уклонов минерального дна и современной поверхности в результате интенсивного торфонакопления. На границе березово-сосново-кустарничково-пушицево-сфагнового болота и кедрово-сосново-березового болотнотравного заболоченного леса выделен участок повышения минерального дна, в настоящее время с практически ровной поверхностью (угол наклона менее $0,1^{\circ}$ ). Участок характеризуется максимальным значением увлажненности местообитания при практически полном отсутствии торфяной залежи. Максимальные значения углов наклона современной поверхности $0,2-0,3^{\circ}$ соответствуют участку заболоченного леса на некотором 
удалении от границы Бакчарского болотного массива. В пределах изолированного понижения произошло уменьшение средних значений углов наклона до $0-0,15^{\circ}$.

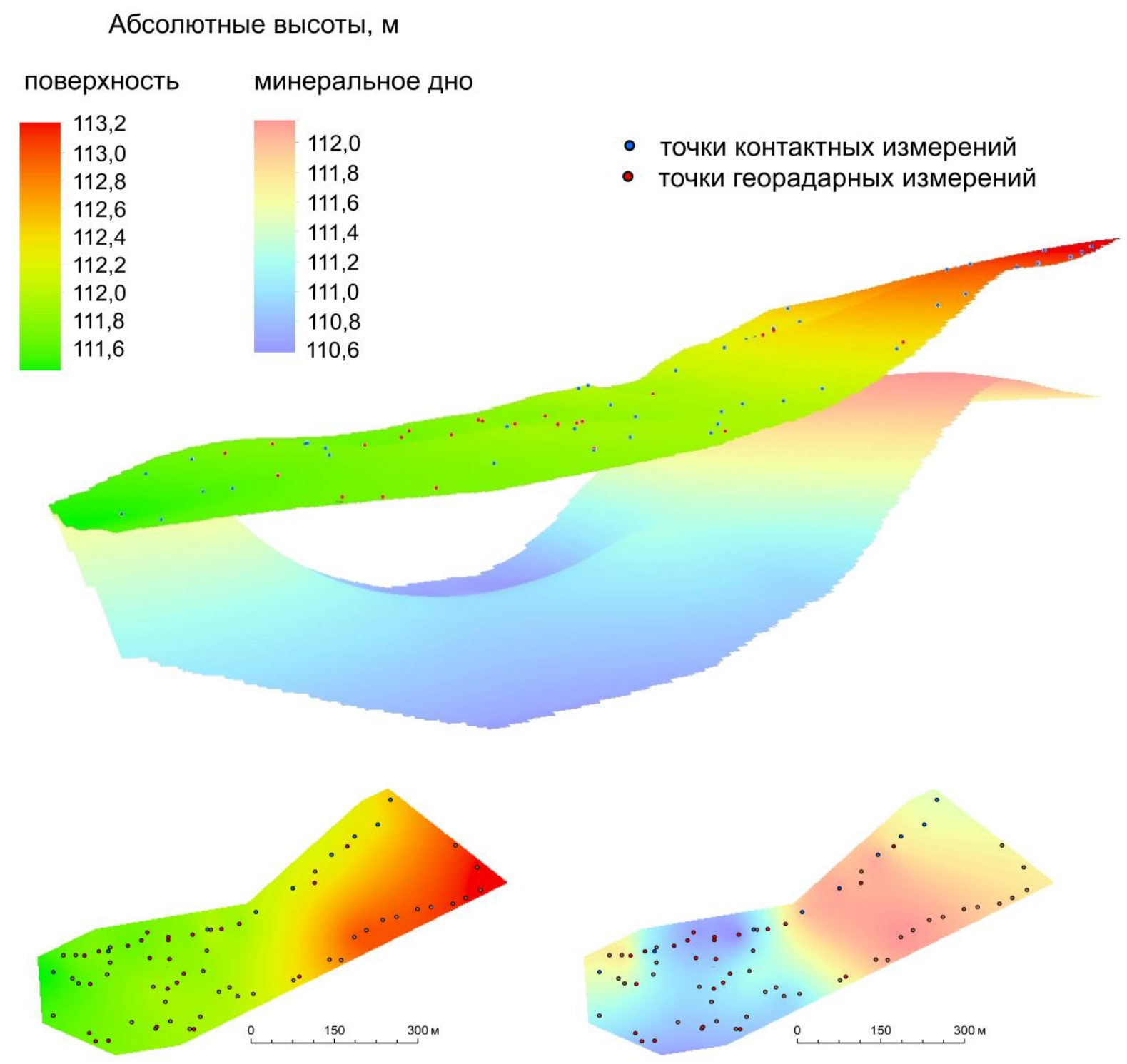

Рисунок 5. Цифровые модели рельефа современной поверхности и минерального дна ключевого участка

\section{ОБСУЖДЕНИЕ РЕЗУЛЬТАТОВ}

Пространственные закономерности в изменении видового состава растительного покрова, увлажнения местообитаний и мощности торфяной залежи при удалении от болотного массива не выявлены, что указывает на влияние комплекса факторов, определяющих состояние и степень гидроморфной трансформации лесоболотных экотонов. В качестве основных факторов рассмотрено влияние уклона минерального дна и поверхности лесоболотного экотона, определяющие условия дренированности территории в зоне влияния болотного массива. Статистический анализ полученных в рамках проведения исследования данных с использованием метода главных компонент позволил оценить влияние некоторых геоморфологических показателей на характеристики растительного покрова заболоченных лесов. Углы наклона современной поверхности находятся в обратной зависимости с мощностью торфяной залежи (первая факторная ось), и в меньшей степени оказывают влияние на характеристики растительного покрова (рис.6). Эта закономерность подтверждает полученный в результате геоинформационного 
моделирования вывод о значительном выравнивании поверхности в результате торфонакопления. При увеличении угла наклона минерального дна выявлено уменьшение высоты древесного яруса, увеличение увлажненности местообитания, а также увеличение доли растений, относящихся к 12 и 17 ступеням увлажнения (вторая факторная ось). Склоны котловин с высокими значениями углов наклона поверхности в настоящее время заполнены торфом, и участки характеризуются высокой степенью гидроморфной трансформации. Накопление торфа не только на плоских поверхностях, но и на склонах котловин с углами наклона около $0,5^{\circ}$, обусловлено возможностью накопления торфа при достаточном количестве воды, стекающей с прилегающего верхового болотного массива. Влияние рельефа минерального дна на состояние лесоболотного экотона неоднозначно, что выражено в увеличении доли растений, относящихся как к условиям относительно сухих, так и влажных местообитаний в пределах ключевого участка. Это может объясняться высокой степенью расчленения поверхности, возрастающей с увеличением увлажненности участка. Значительные перепады высот между положительными и отрицательными формами микрорельефа определяют различия в условиях произрастания видов и, как следствие, увеличение видового разнообразия и появлением видов свежелуговой экологической группы на высоких положительных формах микрорельефа.

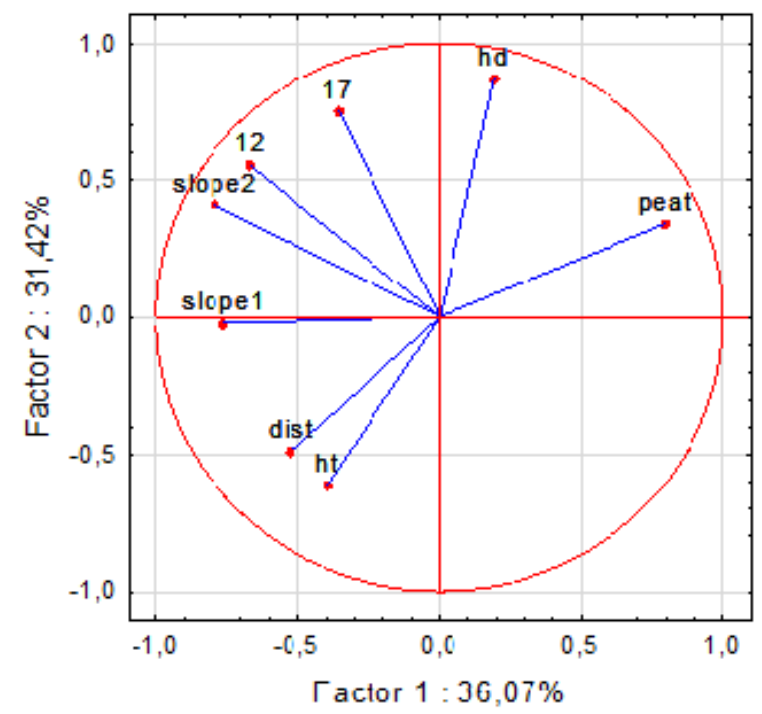

Рисунок 6. Результаты факторного анализа показателей основных компонентов ландшафта: dist расстояние от границы болотного массива; slope1 - угол наклона поверхности; slope2 - угол наклона минерального дна; peat - мощность торфяной залежи; ht - высота древесного яруса; hd увлажненность местообитания; 12 - удельный вес проективного покрытия видов 12 ступени увлажнения; 17 - удельный вес проективного покрытия видов 17 ступени увлажнения.

В свою очередь показатели микрорельефа поверхности находятся в тесной взаимосвязи с характеристиками древесного яруса, мощностью торфяной залежи и степенью увлажнения местообитания. Проведенный факторный анализ позволил разделить переменные на три факторные оси, первая из которых объединяет показатели микрорельефа, отражающие распределение высот относительно средней поверхности, долю сосны в составе древесного яруса и мощность торфа (рис.7). При увеличении мощности торфа и появлении сосны в древесном ярусе отмечено увеличение доли высот выше средней поверхности и уменьшение доли высот в интервале -5-5 см около средней поверхности. Ко второй факторной оси относятся общая сомкнутость крон древесного яруса и среднеквадратическое отклонение высот микрорельефа, находящиеся в прямой зависимости. Полученная закономерность подтверждает гипотезу качественной характеристики микрорельефа заболоченного леса о генезисе положительных форм микрорельефа за счет образования приствольных повышений и поваленных стволов, при отсутствии аккумулятивных форм. Третья факторная ось отражает прямую зависимость степени увлажнения местообитания от амплитуды колебаний высот поверхности. Таким образом, микрорельеф поверхности заболоченных лесов, находящийся в тесной взаимосвязи с характеристиками древесного яруса, оказывает влияние на распределение видов травяно- 
кустарничкового яруса, обеспечивая расширение видового разнообразия за счет появления видов, характерных для более сухих местообитаний.

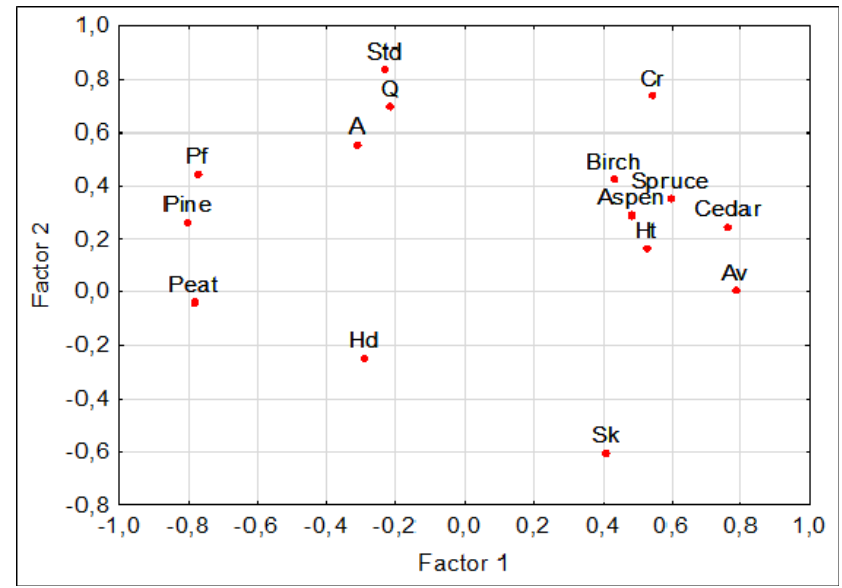

Рисунок 7. Результаты факторного анализа показателей микрорельефа и растительности.

A - амплитуда; Q - квартильный размах; Std - среднеквадратическое отклонение; Av - доля высот у средней поверхности; Pf - доля высот выше средней поверхности; Sk - коэффициент асимметрии; Birch - доля березы; Pine - доля сосны; Cedar - доля кедра; Aspen - доля осины; Spruce - доля ели; $\mathrm{Cr}$ - общая сомкнутость крон; Ht - высота древесного яруса; $\mathrm{Hd}$ - степень увлажнения; Peat - мощность торфа.

Таким образом, морфометрические показатели поверхности дают меньший вклад в объяснение пространственной дифференциации растительности в сравнении с морфометрией минерального дна. Форма минерального дна, определяющая гидрологические условия начала процесса торфонакопления, продолжает оказывать влияние на развитие процесса заболачивания и в настоящее время, что также подтверждается исследованиями (Graniero, Price, 1999). Развитие процесса заболачивания в зоне влияния болотного массива будет зависеть от топографии минерального дна с учетом новых условий увлажнения, создаваемых в результате трансформации исходной поверхности.

\section{ЗАКЛЮЧЕНИЕ}

В результате комплексной оценки состояния лесоболотного экотона Бакчарского болотного массива с использованием традиционных и современных методов получены новые данные о почвенно-растительном покрове, микрорельефе поверхности заболоченных лесов, находящихся в зоне влияния верхового болотного массива. Представлены данные о трансформации поверхности в результате торфонакопления, проведена оценка влияния морфометрических показателей рельефа поверхности и минерального дна на состояние растительного покрова заболоченных лесов. По результатам геоинформационного моделирования поверхности и минерального дна ключевого участка выявлено снижение среднего угла наклона с $0,23^{\circ}$ до $0,15^{\circ}$ в результате торфонакопления, при этом мощность торфяной залежи находится в обратной зависимости от углов наклона современной поверхности. Выравнивание поверхности лесоболотного экотона будет способствовать дальнейшей гидроморфной трансформации ключевого участка. По результатам оценки растительного покрова с использованием экологической шкалы увлажнения местообитания отмечено, что большая часть ключевого участка относится к сыро-лесолуговой ступени увлажнения, при этом наиболее увлажненным является участок в непосредственной близости с границей Бакчарского болотного массива. Отмечено, что уклон минерального дна продолжает оказывать влияние на состояние растительного покрова и условия увлажнения местообитания. Статистически подтверждено влияние расчлененности поверхности на увлажнение местообитания, что делает целесообразным использование количественных показателей микрорельефа при оценке гидроморфной трансформации лесоболотных экотонов. Количественная оценка вклада рельефа, как основного фактора формирования болот, полученная с использованием современных методов исследования, может быть использована как основа для разработки прогнозных моделей процессов заболачивания прилегающих к болотам территорий и оценки роли расширения площадей болот в динамике глобального цикла углерода. 


\section{БЛАГОДАРНОСТИ}

Работа выполнена при финансовой поддержке РФФИ в рамках научного проекта № 18-3500387 -мол_а

\section{ЛИТЕРАТУРА}

1. Бабиков Б.В., Кобак К.И. Поглощение атмосферного углекислого газа болотными экосистемами территории России в голоцене. Проблемы заболачивания // Известия высших учебных заведений. Лесной журнал. 2016. № 1(349). C. 6-36. doi: 10.17238/issn0536-1036.2016.1.9

2. Евсеева Н.С., Синюткина А.А., Харанжевская Ю.А. и др. Ландшафты болот Томской области. Томск: Изд-во НТЛ, 2012. 400 с.

3. Инишева Л.И., Березина Н.А. Возникновение и развитие процесса заболачивания на Западно-Сибирской равнине // Вестник Томского государственного университета. 2013. № 366. С. 172-179.

4. Камиро М.А., Синюткина А.А., Гашкова Л.П. Особенности интерпретации данных георадиолокационной съемки почвенного покрова лесоболотных экотонов // Почвы в биосфере: Сборник материалов Всероссийской научной конференции с международным участием, посвященной 50-летию Института почвоведения и агрохимии СО РАН. (Новосибирск, 10-14 сентября 2018 г.). Томск, 2018. Ч. ІІ. С. 380-384.

5. Лисс О.Л., Абрамова Л.И., Аветов Н.А. и др. Болотные системы Западной Сибири и их природоохранное значение. Тула: Гриф и К, 2001. 584 с.

6. Никифоров А.Н., Дюкарев А.Г. Почвы заболоченных ландшафтов восточных склонов Васюганской равнины // Отражение био-, гео-, антропосферных взаимодействий в почвах и почвенном покрове: Сборник материалов V Международной научной конференции (Томск, 7-11 сентября 2015 г.). Томск, 2015. С. 65-67.

7. Почвоведение. Типы почв, их география и использование. Под ред. В.А. Ковды, Б.Г. Розанова. Часть 2.Москва: Высшая школа, 1988. 368 с.

8. Прокопьев Е.П. Экология растений (особи, виды, экогруппы, жизненные формы). Томск: Томский государственный университет, 2001. 340 с.

9. Западная Сибирь / Под ред. Рихтер Г.Д.. М.: Издательство АН СССР, 1963. 488 с.

10. Синюткина А.А., Гашкова Л.П., Каширо М.А. Изучение пространственной дифференциации лесоболотных экотонов с использованием методов георадиолокации // Почвы в биосфере: Сборник материалов Всероссийской научной конференции с международным участием, посвященной 50-летию Института почвоведения и агрохимии СО РАН. (Новосибирск, 10-14 сентября 2018 г.). Томск, 2018а. Ч. ІІ. С. 423-426.

11.Синюткина А.А., Гашкова Л.П., Малолетко А.А., Магур М.Г., Харанжевская Ю.А. Трансформация поверхности и растительного покрова осушенных верховых болот юго-востока Западной Сибири // Вестн. Том. гос. ун-та. Биология. 2018b. № 43. С. 196-223. doi: 10.17223/19988591/43/10

12.Синюткина А.А., Рочев В.В., Малолетко А.А. Оценка мозаичности болот таежной зоны Западной Сибири// Двенадиатое Сибирское совещание и школа молодых ученых по климато-экологическому мониторингу. Тезисы докладов российской конференции (Томск, 17-20 октября. Томск, 2017. С. 175-176.

13.Тюремнов С.Н. Торфяные месторождения. Москва: Недра, 1976. 488 с.

14.Цыганов Д.Н. Фитоиндикация экологических режимов в подзоне хвойно-широколиственных лесов. М: Наука, 1983. 197 с.

15. Чудиновская Л.А., Синюткина А.А. Картографирование растительных сообществ окраинных частей Большого Васюганского болота // Перспективы развития и проблемы современной ботаники: Материалы IV(VI) Всероссийской молодежной конференции с участием иностранных ученых (Новосибирск, 8-12 октября 2018 г.). Новосибирск, 2018. С. 244-247.

16. Graniero P.A., Price J.S. The importance of topographic factor on the distribution of bog and heath in a Newfoundland blanket bog complex // Catena. 1999. №36. Iss.3. P. 233-254. doi: 10.1016/S0341-8162(99)00008-9 17.Laamrani A, Valeria O., Bergeron Y., Fenton N., Cheng L., Anvomi K. Effect of topography and thickness of organic layer on productivity of black spruce boreal forest of Canadian Clay Belt region // Forest Ecology and Management. 2014. №330. P. 144-157. doi: 10.1016/j.foreco.2014.07.013

18. Sass O., Friedmann A., Haselwanter G., Wetzel K.-F. Investigating thickness and internal structure of alpine mires using convention and geophysical techniques // Catena. 2010. №80. Iss. 3. P. 195-203. doi: 10.1016/j.catena.2009.11.006

19. Ulriksen P. Investigation of peat thickness with radar // Proc. of 6th Int. Peat Congress, Duluth, Minnesota, August 1980. P. 126-129.

20.Walter J., Hamann G., Luck E., Klingenfuss C., Zeitz J. Stratigraphy and soil properties of fens: Geophysical case studies from northeastern Germany // Catena. 2016. №142. P.112-125. doi: 10.1016/j.catena.2016.02.028

Поступила в редакичию 05.11.2018

Принята 03.12.2018

Опубликована 29.12.2018 


\title{
Сведения об авторах:
}

Синюткина Анна Алексеевна - кандидат географических наук, старший научный сотрудник научного отдела Сибирского научно-исследовательского института сельского хозяйства и торфа - филиала Сибирского федерального научного центра агробиотехнологий РАН (Томск, Россия); ankalaeva@yandex.ru

Гашкова Людмила Павловна - младший научный сотрудник, научный отдел Сибирского научно-исследовательского института сельского хозяйства и торфа - филиала Сибирского федерального научного центра агробиотехнологий $\mathrm{PAH}$; аспирант кафедры географии Национального исследовательского Томского государственного университета (Томск, Россия); gashkova-lp@rambler.ru

Авторы прочитали и одобрили окончательный вариант рукописи

$($ cc) EҮ $\square$ Статья доступна по лицензии Creative Commons Attribution 4.0 License

\section{ASSESSMENT OF THE STATUS OF THE BAKCHAR BOG MARGINAL PART OF THE GREAT VASYUGAN MIRE}

\section{(C) 2018 A.A. Sinyutkina, L.P. Gashkova}

\author{
Address: Siberian Research Institute of Agriculture and Peat - branch of the Siberian Federal Scientific \\ Center of Agro-Bio Technologies of the Russian Academy of Sciences, Tomsk, Russian. \\ E-mail:ankalaeva@yandex.ru
}

\begin{abstract}
The aim of the study. The aim of the study was to assess the status of the forest-mire Bakchar bog ecotone (southern taiga subzone of Western Siberia) of the Great Vasyugan mire.

Location and time of the study. The key study site was located in the basin of the River Klyuch $\left(56^{\circ} 58^{\prime} \mathrm{NL}\right.$, $82^{\circ} 36$ EL). The study was conducted in 2017-2018.

Methodology. The georadiolocation method, field landscape studies and geoinformation modeling methods were used.

Main results. The study site was dominated by the mired birch-dominated forest on peat shallow soils. The surface microtopography is strongly partitioned, with the average value of the height standard deviation of 14 and the average amplitude of height fluctuation $58.4 \mathrm{~cm}$. The amplitude of the height fluctuations directly determines the habitat moisture content, which makes it advisable to use quantitative microtopography parameters for assessing hydromorphic transformation of forest-mire ecotones. The main part of the territory may be categorized as the damp-forest-meadow stage of moistening, scoring 14,2-15,7 according to the ecological scale of D.N. Tsyganov. Statistical analysis showed that habitat moisture is mainly determined by its mineral bottom gradient, and the peat deposit thickness is directly dependent on the contemporary surface gradient. As a result of peat accumulation, the surface was leveled and the average gradient decreased from $0.23^{\circ}$ to $0.15^{\circ}$, thus contributing to the further hydromorphic transformation of the site. Conclusion. The comprehensive assessment of the status of the forest-mire ecotone of the Bakchar mire provided new information about ground surface transformation due to peat accumulation. Quantitative estimate of the relief role as a main factor of mire development in the area was obtained. This new information can be used as a basis to develop prognostic models of mire development and growth in the areas adjacent to them and to evaluate the role of potentially increased mire areas in the global carbon cycle.
\end{abstract}

Key words: geoinformation modeling; GPR; mired forest; microtopography; peat deposit; mire development

How to cite: Sinyutkina A.A., Gashkova L.P. Assessment of the status of the Bakchar bog marginal part of the Great Vasyugan mire // The Journal of Soils and Environment. 2018. 1(4): 243 -255. (in Russian with English abstract).

\section{REFERENCES}

1. Babikov B.V., Kobak K.I. Absorption of Atmospheric Carbon Dioxide by the Wetland Ecosystems of Russia in Holocene. The Problems of Paludification, Bulletin of Higher Educational Institutions. Lesnoyzhurnal (Forestry journal), 2016, No1(349), p. 6-36. doi: 10.17238/issn0536-1036.2016.1.9 (in Russian)

2. Evseeva N.S., Sinyutkina A.A. Kharanzhevskaya Yu.A. et al. Landscape of the mires in Tomsk Region, 2012, Tomsk: Publishing house of NTL, 400 p. (in Russian)

3. Inisheva L.I., Berezina N.A. Origin and development of mire formation process in West-Siberian plain, Tomsk State University Journal, 2013, No 366, p. 172-179. (in Russian) 
4. Kashiro M.A, Sinyutkina A.A., Gashkova L.P. Peculiarities of data interpretation GPR survey of soil cover of forest-bog ecotones. In book: Soils in Biosphere / Proc. of the Rus. Sci. Conf. with international participation, dedicated to the $50^{\text {th }}$ anniversary of the Institute of Soil Science and Agrochemistry of the SB RAS, (Novosibirsk, 10-14 September, 2018 ), Tomsk, 2018, V. II, p. 380-384. (in Russian)

5. Liss O.L., Abramova L.I., Avetov N.A., Berezina N.A., Inisheva L.I., Kurnishkova T.V., Sluka Z.A., Tolpysheva T.Ju., Shvedchikova N.K. Swamp systems of Western Siberia and their conservation role. Tula: Grif and K, 2001. 584 p. (in Russian)

6. Nikiforov A.N., Diukarev A.G. Waterlogged soil landscapes of the eastern slopes Vasyugan Plain, Reflection bio-geoantroposferalinteracntions in soils and soil cover / Proc. of the $\mathrm{V}^{\text {th }}$ Int. Sci. Conf. dedicated to the 85th anniversary of the Department of Soil Science and Soil Ecology, TSU. , Tomsk, 2015, p. 65-67.

7. Soil Science. Soil types, their geography and use. V.A. Kovda, B.G. Rozanov (ed.), Moscow, Vysshaya shkola Pbs., 1988, 368 p. (in Russian)

8. Prokop'ev E.P. Plant ecology (individuals, species, eco groups, life forms). Tomsk, TSU Pbs., 2001, 340p. (in Russian)

9. West Siberia / Rikhter G.D. (ed.). Moscow, Izdatel'stvo AN SSSR, 1963, 488 p. (in Russian)

10. Sinyutkina A.A., Gashkova L.P., Kashiro M.A. Georadiolocation studyes of the spatial differentiation of forest and mire ecotons. In book: Soils in Biosphere / Proc. of the Rus. Sci. Conf. with international participation, dedicated to the $50^{\text {th }}$ anniversary of the Institute of Soil Science and Agrochemistry of the SB RAS, (Novosibirsk, 10-14 September, 2018 ), Tomsk, 2018a, V. II, p. 423-426. (in Russian)

11. Sinyutkina A.A., Gashkova L.P., Maloletko A.A., Magur M.G., Kharanzhevskaya Yu.A. Transformation of the surface and vegetation cover of drained bogs in Tomsk region, Tomsk State University Journal of Biology, 2018b, No43, p. 196-223. doi: 10.17223/19988591/43/10 (in Russian)

12. Sinyutkina A.A., Rochev V.V., Maloletko A.A. Estimation of the swag mosaicity of the taiga zone in the Western Siberia, The XII ${ }^{\text {th }}$ Siberian Meeting and School of Young Scientists on Climate and Ecological monitoring: Abstracts of reports on All-Rus. Conf. (Tomsk, 17-20 October 2017), Tomsk, 2017. p. 175-176. (in Russian)

13. Tyuremnov S.N. Peat deposits. Moscow, Nedra Pbs, 1976, 488 p. (in Russian)

14. Tsyganov D.N. Phytoindication of ecological regimes in the subzone of coniferous-deciduous forests, Moscow, Nauka Pbs, 1983, 197 p. (in Russian)

15. Chudinovskaya L.A., Sinyutkina A.A. Mapping of plant communities of the marginal parts of the Great Vasyugan Mire, Prospects for development and problems of modern botany / Proc. of the $\mathrm{IV}^{\text {th }}$ Rus. Youth Conf. with the participation of foreign scientists (Novosibirsk, October 8-12, 2018), Novosibirsk, 2018, p. 244-247. (in Russian)

16. Graniero P.A., Price J.S. The importance of topographic factor on the distribution of bog and heath in a Newfoundland blanket bog complex, Catena, 1999, No36, Iss.3, p. 233-254. doi: 10.1016/S0341-8162(99)00008-9

17. Laamrani A, Valeria O., Bergeron Y., Fenton N., Cheng L., Anvomi K. Effect of topography and thickness of organic layer on productivity of black spruce boreal forest of Canadian Clay Belt region, Forest Ecology and Management, 2014, $N^{o} 330$, p. 144-157. doi: 10.1016/j.foreco.2014.07.013

18. Sass O., Friedmann A., Haselwanter G., Wetzel K.-F. Investigating thickness and internal structure of alpine mires using convention and geophysical techniques, Catena, 2010, N $N^{\circ} 80$, Iss. 3, p. 195-203. doi: 10.1016/j.catena.2009.11.006

19. Ulriksen P. Investigation of peat thickness with radar, Proc. of $6^{\text {th }}$ Int. Peat Congress, Duluth, Minnesota, August 1980, p. 126-129.

20. Walter J., Hamann G., Luck E., Klingenfuss C., Zeitz J. Stratigraphy and soil properties of fens: Geophysical case studies from northeastern Germany, Catena, 2016, No142, p. 112-125. doi: 10.1016/j.catena.2016.02.028

Received 05 November 2018

Accepted 03 December 2018

Published 26 December 2018

\section{About the authors:}

Sinyutkina Anna A. - Candidate of Geographical Sciences, Senior Researcher of Siberian Research Institute of Agriculture and Peat, Siberian Federal Scientific Centre of Agro-Biotechnologies (Tomsk, Russia); ankalaeva@yandex.ru

Gashkova Ludmila P. - Researcher, Siberian Research Institute of Agriculture and Peat, Siberian Federal Scientific Centre of Agro-Biotechnologies, Tomsk, Russian Federation, also a post-graduate student at the Department of Geography, National Research Tomsk State University (Tomsk, Russia); gashkova-lp@rambler.ru

The authors read and approved the final manuscript

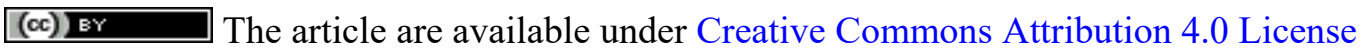

